\title{
Change of government in the Guba region of Azerbaijan and its tragic consequences (1920-1921)
}

\author{
Rakhshanda Bayramova, Institute of History named after A. A. Bakikhanov of the Azerbaijan \\ National Academy of Sciences
}

One of the steps taken by the new government in the political sphere was the abolition of the former national army. On May 7, the Revolutionary Committee of Azerbaijan decided to reorganize the army and navy. According to the decision, the new Azerbaijani army and navy were, in fact, created as part of the Red Army of Soviet Russia. Azerbaijani military units were directly subordinated to the commander of the XI Red Army, and warships to the command of the Caspian fleet. Thus, from the first months of its existence, the Soviet Republic of Azerbaijan "voluntarily" renounced the right to have an armed force, which is one of the important conditions of statehood. the Soviet authorities and the 11th Army were accused of open looting in Azerbaijan under the name of "confiscation of the property of the bourgeoisie." After the establishment of Soviet power in Guba, the old system of administrative management was completely abolished and a new administrative system - the Soviet system - was established. The article "Change of government in the Guba region of Azerbaijan and its tragic consequences" concerns the issue about the reactivation of the Armenians in Karabakh and Zangazur, the Azerbaijani army units defending the northern border - Guba. The paper was dedicated to the situation in the militia system improved relatively in the late 1920s. Tha aim of the study is to determine conditions the formation of new government structures in remote villages continued until mid-1921 under the influence of a number of factors. In this context, issues of the Communist newspaper were first listed, number of militiamen in the Guba district was determined, avtivities to increase technical training, communist centers, people's attitude towards the militia were analyzed. This analysis was conducted with the study of the sources related to the subject, the analysis of the results obtained, the analysis and synthesis of the arguments, and also the comparative analysis method.

Keywords: change of government, Guba district, Azerbaijan, Gusar, Revolutionary Committee, Soviet system, XI Red Army

\section{Зміна уряду в регіоні Губи в Азербайджані та його трагічні наслідки (1920-1921)}

\section{Рахшанда Байрамова, Інститут історії імені А. А. Бакіханова Азербайджанської національної академії наук}

Одним із кроків, здійснених новим урядом у політичній сфері, було скасування колишньої національної армії. 7 травня Ревком Азербайджану ухвалив рішення про реорганізацію армії та флоту. Згідно з рішенням нова азербайджанська армія та флот фактично були створені у складі Червоної армії Радянської Росії. Азербайджанські військові частини безпосередньо підпорядковувались командувачу ХІ Червоної Армії, а військові кораблі - командуванню Каспійським флотом. Таким чином, $з$ перших місяців свого існування Азербайджанська Радянська Республіка «добровільно» відмовилася від права мати збройні сили, що є однією з важливих умов державності. Радянську владу та 11-ю армію звинуватили у відкритому мародерстві в Азербайджані під назвою «конфіскація майна буржуазії». Після встановлення радянської влади в Губі стара система адміністративного управління була повністю скасована і нова адміністративна система - радянська. Стаття «Зміна уряду в регіоні Губи в Азербайджані та ії трагічні наслідки» стосується питання про реактивацію вірмен у Карабаху та Зангазурі, підрозділи азербайджанської армії, які захищають північний кордон - Губу. Стаття присвячена ситуації в системі міліції, яка покращилася відносно періоду наприкінці 1920-х років. Метою дослідження $є$ визначення умов формування нових урядових структур у віддалених селах, що тривали до середини 1921 р., під впливом низки факторів. У цьому контексті вперше були перераховані випуски комуністичної газети, визначена кількість міліціонерів у Губському районі, 
проаналізовані заходи з підвищення технічної підготовки, комуністичні центри, ставлення людей до міліції. Цей аналіз проводився з вивченням джерел, що стосуються предмета, аналізом отриманих результатів, аналізом та синтезом аргументів, а також методом порівняльного аналізу.

Ключові слова: зміна влади, округ Губа, Азербайджан, Гусар, революиійний комітет, радянська система, ХІ Червона Армія

\title{
Смена власти в Губинском районе Азербайджана и ее трагические последствия (1920-1921 гг.)
}

\author{
Рахшанда Байрамова, Институт истории имени А. А. Бакиханова Национальной \\ Академии Наук Азербайджана
}

Одним из шагов, предпринятых новым правительством в политической сфере, стало упразднение бывшей национальной армии. 7 мая Революционный комитет Азербайджана принял решение о реорганизации армии и флота. Согласно постановлению новая азербайджанская армия и флот фактически были созданы в составе Красной армии Советской России. Азербайджанские воинские части подчинялись непосредственно командующему XI Красной армии, а боевые корабли - командованию Каспийского флота. Таким образом, Азербайджанская Советская Республика с первых месяцев своего существования «добровольно» отказалась от права иметь вооруженные силы, что является одним из важных условий государственности. Советские власти и 11-я армия были обвинены в открытом мародерстве в Азербайджане под названием «конфискация имущества буржуазии», после установления Советской власти в Губе старая система административного управления была полностью упразднена и была создана новая административная система - советская система. В статье «Смена правительства в Губинском районе Азербайджана и ее трагические последствия» затрагивается вопрос о реактивации армян в Карабахе и Зангезуре, частей азербайджанской армии, защищающих северную границу - Губу. Статья была посвящена ситуации в системе милиции, относительно улучшившейся в конце 1920 -х годов. Цель исследования - определить условия, при которых формирование новых государственных структур в отдаленных деревнях продолжалось до середины 1921 г. под влиянием ряда факторов. В этом контексте первыми были перечислены номера газеты «Коммунист», определена численность милиционеров в Губинском районе, проанализированы направления повышения квалификации, коммунистические центры, отношение населения к милиции. Этот анализ проводился с изучением источников, связанных с предметом, анализом полученных результатов, анализом и обобщением аргументов, а также методом сравнительного анализа.

Ключевые слова: смена правительства, Губинский район, Азербайджан, Гусар, ревком, советский строй, ХІ Красная Армия

\section{Introduction.}

T $\mathrm{n}$ the spring of 1920 , due to the reactivation of the Armenians in Karabakh and Zangazur, the Azerbaijani army units defending the northern border Guba, Baku infantry regiments, units of the Tatar cavalry regiment were sent to Karabakh, as a result, the northern borders remained unprotected. The new military situation created another threat for Azerbaijan - Bolshevism. As the Bolshevik troops advanced south, this threat became a reality. As the Azerbaijani army conducted military operations in Karabakh and Zangazur, conditions were created for the XI
Red Army from the north to enter Azerbaijan without hindrance and capture Baku in a short time. The Red Army command was well aware of this. The political situation in Baku and the crisis of power also increased the chances of aggression. The Bolshevik leadership of Russia had detailed information about the protection of the northern borders of Azerbaijan.

\section{Discussion.}

I. Dudin, who was a member of the Red Army and later wrote about these events, also mentions this in his memoirs (Dudin, 1970, p. 37-38). On March 28, 1920, the city of Petrovsk was captured by the XI Red Army. 
After the victory of the Bolshevik regime in the North Caucasus over Denikin's forces, the local Bolsheviks in Baku and other regions, as well as in Guba, with the military-political and financial support of Russia and the Baku Bolsheviks, engaged in open provocations against the Azerbaijani statehood. The letter of the Prime Minister N.B Yusifbeyli to the Minister of Internal Affairs dated March 8, 1920 stated that the Bolsheviks of Dagestan received humanitarian and material assistance from the Bolsheviks of Azerbaijan, who were required to take all measures to prevent the Bolsheviks from crossing from Azerbaijan to Dagestan and vice versa (ARDA, work 18, v. 24).

Inspired by the victory of the Bolsheviks during the Russian civil war, the local Bolsheviks also revolted. The Bolsheviks carried out open propaganda even among the soldiers of the Guba garrison. This was confirmed by the chief of the Guba district Talibkhanov in his letter to the governor of Baku dated March 11, 1920 (ARDA, work 18, v. 80). The Bolsheviks even had their own party core in the garrison (ARDA, work 18 , v. 10). In order to prevent the propaganda of the Bolsheviks among the soldiers, the garrison chief Mammadbayov, together with the division commander, began to take emergency measures to identify and punish the propagandists. In order to protect the garrison soldiers from the influence of Bolshevik propaganda, they were isolated and forbidden to go to various barracks and teahouses, as well as the entry of outsiders was forbidden into barracks (ARDA, work 26, v. 37). In order to prevent the Bolsheviks from entering Azerbaijan, by the order of the chief of the Guba district Agabeyov, security was organized in two places along the border with Dagestan - Yalama and Hazra districts. A group of 20 local residents guarded the villages of Lajat and Khudat. The border was guarded by the people's militia and postal guards. The Gusar police officer was instructed to form a group of local residents to help the police. The district chief also instructed the field chiefs to pay more attention to border protection. Measures were also intensified to fight the Bolsheviks inside the district and to prevent the activities of those who carried out Bolshevik propaganda (ARDA, work 32, v. 2) .

On the eve of the occupation of Azerbaijan, units of the XI Red Army were already in Derbent, guarding the railway line by maneuvering between the armored trains and the bridge over the Derbent and Samur rivers. The personnel of the Red Army consisted of 72,472 people (Suleymanov, 1998, p. 438). On the eve of the occupation, the Guba Bolsheviks also became more active. By order of the AKP Central Committee, armed groups consisting of anti-state elements were organized, and an armed uprising headquarters was established. It was decided to use the help of military units and local volunteer groups in Guba to protect the unprotected border. Acting commander of the 4th Guba Infantry Regiment N. Tumanov told A.A Shikhlinsky that in order to strengthen the military units in Khachmaz and to receive information about the enemy, to organize reconnaissance operations, 4 companies from Guba, 3 armored trains, from Yalama and 70 were sent (Azerbaijan Democratic Republic, 1998, p. 374). On the night of April 27, 1920, the occupying forces violated the Azerbaijani border with five armored trains and launched a military aggression against the independent state. Although a small number of units of the Azerbaijani army resisted in Yalama and later in Khudat and Khachmaz stations, it was not possible to prevent the occupying forces due to the inequality of forces (Tokarzhevsky, 1957, p. 269).

There were only 3,000 forces on the northern border, and these forces were scattered along the border and stationed mainly in the Gusar-GubaKhudat region. Under warrant officer Babayev's command, two companies, a machine gun team and a cavalry division were forced to retreat after unequal battles. Although the enemy was resisted at the Lajat crossing and Khudat station, it was not possible to prevent it. Following the armored train, in the early morning of April 27, the 7 th cavalry and 31 st infantry divisions of the Red Army crossed the border and entered the village of Gullar in Guba district. The Gusar garrison surrendered without resistance. On the same day, the cavalry regiments of the 7 th division captured the city of Guba. According to Tokarjevsky, 31 officers and 500 soldiers of the Azerbaijani army were captured in Guba and Gusar, and 5,000 soldiers were captured during the intervention (Tokarzhevsky, 1957, p. 269).

Thus, the occupying forces, occupying the entire territory of Guba district in one day, occupy the entire territory of Azerbaijan in a short time and put an end to the existence of an independent state - the Republic of Azerbaijan. 
At that time, the units of the Azerbaijani army located in Guba district were subordinated to the 20th division of the XI Red Army. Thus, the land of Guba entered a new stage - the Soviet era. It was decided to abolish all government structures created during the republican period. By the decision of the Revolutionary Committee of May 3, 1920, the activities of all counter-revolutionary parties and organizations were banned. On the same day, the AK (b) P Guba district committee was established under the chairmanship of F. Abbasov. Although the Provisional Revolutionary Committee of Azerbaijan and the Council of People's Commissars of the Azerbaijan SSR, which were established in Azerbaijan after the coup and concentrated all state power in their hands, were composed of Azerbaijanis, it was only apparently that the newly created Soviet republic was governed by Moscow. The Bolsheviks, speaking on behalf of the people, called the state a proletarian dictatorship. This was a kind of political veil for the ruling Bolshevik Party. The real power belonged to the AK (b) P, a local branch of the RK (b) P. The Azerbaijani Communist Party and the Baku party organization, whose core consisted of non-nationals, mainly Russians and Armenians, played a leading role in the socio-political life of the republic. One of the factors that ensured the dictatorship of the Communist Party in Azerbaijan was the Russian army units here. After the April occupation, the independence of the republic was completely formal.

After the collapse of the national government, red terror began against the people of Azerbaijan. The Extraordinary Commission on Combating Counter-Revolutionary Sabotage and Fraud was established, and the Supreme Revolutionary Tribunal was established. The Workers 'and Peasants' Inspectorate was established on June 9, 1920 to monitor the activities of state organizations and public organizations. In this case, they were given special powers. Thus, the work of the Emergency Commission and the Supreme Revolutionary Tribunal was not limited by any legislation, their decision and verdict were final and implemented immediately. These organizations were directly subordinated to the army command and the center - Moscow. Therefore, the Azerbaijani government had almost no control over the activities of these organizations (Ibrahimli, 1996, p. 31). From the first days of Soviet rule in Azerbaijan, the special unit of the 11th Army began to ruthlessly attack all existing political forces except the Communists, even liberal-minded people and intellectuals. According to some reports, 48,000 people were shot in Azerbaijan from April 1920 to August 1921 (Journal of the Revival, 2008, p. 387). One of the steps taken by the new government in the political sphere was the abolition of the former national army. On May 7, the Revolutionary Committee of Azerbaijan decided to reorganize the army and navy. According to the decision, the new Azerbaijani army and navy were, in fact, created as part of the Red Army of Soviet Russia. Azerbaijani military units were directly subordinated to the commander of the XI Red Army, and warships to the command of the Caspian fleet. Thus, from the first months of its existence, the Soviet Republic of Azerbaijan "voluntarily" renounced the right to have an armed force, which is one of the important conditions of statehood. AXC army officers were repressed. From the April occupation to 1921, 12 generals, 24 colonels and lieutenants, 46 captains and 266 servicemen were shot dead by Azerbaijani servicemen (Hummat, 2008, p. 386).

The XI Red Army, behaving like a real occupying army, was severely interfering in all spheres of the republic. After the April coup, confiscation operations with the direct participation of Soviet troops were accompanied by special brutality. Food agents with official documents from the state, members of the special unit of the XI Army and the Emergency Commission entered homes, confiscated items, degraded human dignity in the true sense of the word, disrespected national and moral values and traditions. The Revolutionary Committee of Azerbaijan received thousands of complaints about such criminal acts. Soldiers of the 11th Army appropriated all the ammunition of the Azerbaijani National Army, including 25,000 sets of special uniforms purchased from Italy at the beginning of the year, $75 \%$ of the shoes produced by Tagiyev's factory and the supply of shoes of the XI Army, which was provided with manufactures, became the subject of discussion at the meetings of the Central Committee of the AK (b) P: It was decided to "confiscate all shoes suitable for the army from shops, both openly and secretly, from those engaged in the shoe trade." The army's supply requirements 
put all spheres of economic life in a difficult position. Even the instruction of the chairman of the SFC, N. I. Solovyov, "Send to hell" who was impatient with the next appeal, caused a scandal in the investigation (Ibrahimli, 1996, p. 28). The Soviet army occupying Azerbaijan was the main reference point of the terrorist dictatorship. During this period, the soldiers of the 11th Army, employees of the special department and the emergency commission, who took part in the search in Azerbaijan and its districts, committed actions that were immoral. In December 1920, Sarkiz, the leader of the Baku Communists, proudly celebrated the looting of the 11th Army in Azerbaijan, saying that we had confiscated 200 pounds of silver, 10 pounds of gold, and about 800 gold rings (Journal of Revival, 2008, p. 386).

At the Second Congress of the AK (b) P in October 1920, the Soviet authorities and the 11th Army were accused of open looting in Azerbaijan under the name of "confiscation of the property of the bourgeoisie." Expressing his strong protest, Narimanov said: "When confiscating and entering a Muslim house, it is necessary to know the conditions in which he lived. It is not necessary to remove earrings from a Muslim woman's ear and look for diamonds in her body" (Bayramova, 2007, p. 31). It is also clear from Narimanov's open confession that the Soviet army did not bring "happiness" and "justice" to Azerbaijan. From the very first days, this army proved that it was an occupier and a looter. Witnessing such illegal activities of the Soviet army, N. Narimanov wrote in his letter "On the history of our revolution in the outskirts": "It was a real unplanned robbery. Finally, the organizations themselves began to talk about making a big mistake. These mistakes were repeated throughout Azerbaijan. As a result, a one-volume case was drawn up on the misallocation of goods, the failure of organizations to forget themselves above all else, and the loss of property under the auspices of comrade Sarkis, the main inspirer" (Narimanov, 1992, p. 21).

The Soviet government abolished the governor-generals, the Baku city government, the governor's offices, the city and district police departments, as well as the former court rules and institutions, and established people's courts. As in the districts of the republic, in Guba and in the city, all local executive committees and revolutionary committees were subordinated to the People's Commissariat of Internal Affairs in terms of administrative management (History of Azerbaijan, 1964, p. 20). By the end of August 1920, there were 16 district, 46 district and 435 village revolutionary committees in Azerbaijan. The local revolutionary committees were given extensive emergency powers. On April 28, 1920, a revolutionary committee was formed in Guba under the leadership of Gogoberidze and with the participation of Red Army officers, and its first meeting was held. The meeting determined the composition of the emergency revolution committee consisting of 7 people. These are: chairman - Jamal Omarov; deputies - V. Lyayuvskaya, Y. Agabeyov, A. Talibov; members: B. Gayibov, M. Tahirzade and Abshalumov. On June 12, 1920, by the order of the emergency commissar of Guba district, a new composition of the Guba Revolutionary Committee was formed. The main reason for the change was the poor performance of the previous composition. The new committee included five communists: Ismayilov, Pupkov, Lakhovsky, Abasov and Tahirzade. Then, according to a telegram from the Ministry of Internal Affairs, the number of key members of the Revolutionary Committee was reduced to three: Chairman Ismayilov, Deputy Pupkov, and member Lakhovsky. Secretary Gabriyelova was appointed. The Revolutionary Committee had nine departments: management, housing and communal services, public education, health, labor and social security, land, finance, labor and peasant inspection, and food (ARDA, work 2, v. 83-85).

Teymur Huseynov was appointed head of the newly established management department of the revolutionary committee in Guba district, and Salimbey Agakishiyev and H. Huseynzadeh, who knew the district very well and were the head of the district during ADR, were appointed members. In the archives, two of these three are listed as communists and one as a candidate (ARDA, work 19, v. 92). Apparently, S. Agakishibeyov, who was the head of the district during the Democratic Republic, had already accepted the ideas of communism and began to serve the new government.

After the collapse of the ADR, the city Duma was abolished in Guba, the city economic council was established, and a man named Abbasov was appointed chairman of the council. 
First Agabeyov was appointed head of the utility department, then Lyakovsky. The latter held this position until October 10. However, Tahirov was appointed to the post after it became clear that he did not know the customs of the local population and was incompetent. On October 10, two new divisions were established in this department, and in general the following divisions functioned in the department: enterprise, construction, housing and transport (ARDA, work 2, v. 977). The Guba Department of Public Education has been headed by Asadulla Talibov since July. In the first months after the April occupation, there was a practical struggle for the distribution of power in the district. Thus, the leaders of individual organizations did not show subordination to each other, on the contrary, they claimed greatness. The clashes between the garrison chief and the revolutionary committee were particularly intense. In this regard, an archival document, the report of Petrosyan, a representative of the Provincial Military Commissariat, dated August 23, 1920, is noteworthy. He wrote: "Everywhere there is a struggle for power, everyone is behaving like a great man, and this is a blow to our work. For example, the head of the Guba garrison orders the chairman of the Guba Revolutionary Committee and the emergency military committee to use public funds and declares that they will be arrested if they protest" (ARDA, work 19, v. 4; 225, p. 251).

At the initial stage of the Sovietization, revolutionary committees were also established in the districts of Guba. On April 30, 1920, the Revolutionary Committee was established in Gusar. Chairman of the Committee was Abasov, Deputy Akulov, members were Nureddin Sharif oglu, Grigory Klochkov and Mustafa Gulu Bagirov (ARDA, work 8, v. 33). Chairman of the Revolutionary Committee in Rustov Dashdamir Aliyev, Deputy Nazarov, member Jabarov; Musabayov, chairman of the Devechi Revolutionary Committee, Mayzelis, deputy chairman, and members Jafarov, Chairman of the Revolutionary Committee Alferenko, Deputy Zaysev, member Mansurov were appointed members. During this period, revolutionary committees were formed in the villages as well as in the districts. Certain conditions were met while selecting committee members. The first of these important conditions was that the member to be elected should not be a Musavat member, and the second was that he/she should not be arrested or poor (ARDA, work 6, v. 2-6). The new structure was not easily accepted by the residents of the district, and in the first months it was very difficult to establish revolutionary committees in a number of villages. For example, in the village of Yerfi, residents strongly protested against the establishment of revolutionary committees (ARDA, work 6, v. 2-6).

In general, it was not possible to obtain detailed information about the committees established in the villages of the district and their members. Only the letter dated August 1920 sent to Musabayov by the Gusar Revolutionary Committee contains detailed information about the revolutionary committees established in the villages of the Gusar district and their members. These lists contain information about the mentioned committees, their members and the date of their establishment. (ARDA, work 4 , v. 26). The next change in the activities of the revolutionary committees and the election of their members was made in September. On September 14, 1920, Order No. 36 was sent to all the revolutionary committees of the district, signed by the chairman of the management department of the Guba Revolutionary Committee, S. Agakishibeyov and H. Huseynzade. The order explicitly stated that the strikers elected to some of the revolutionary committees were opposed to Soviet construction and carried out counter-propaganda. They may commit crimes in the future. From now on, signatories should not be elected to committees, or even participate in elections. This order was to be supervised by the chairmen of the local revolutionary committee and the peasant militia. At the end of the order, it was stated that those responsible would be punished if they were negligent and uncontrolled (ARDA, work 19 , v. 50).

In general, 48 Soviet enterprises and organizations were established in Guba district in the first months after the collapse of the Azerbaijan Democratic Republic (Communist, 1920). One of the biggest shortcomings in emergency management after the administrative changes was staff shortages. This issue was mentioned in all the meetings of the district revolutionary committee. There were a number of objective reasons for this situation. Thus, the old state apparatus was completely destroyed during the implementation of revolutionary 
measures in the republic. Many employees and specialists of ministries and head offices either left the country or were subjected to punitive measures. However, many of them were educated in Russia and abroad and gained the necessary work experience in government. The dismissal of these specialists had, in fact, done great damage to the restoration of the national economy and the development of education, science and culture. In general, from the first days of the Soviet power in Azerbaijan, the attitude to the intelligentsia "until April" was predetermined, and a general opinion was formed. Their desire to enter a new life, to serve the country with their knowledge and experience, was presented as a cunning, and their entry into the Soviet administration was presented as an insidious intention. If they had held a certain position during the short period of the ADR's existence, they would have been viewed with suspicion. It can be said that it was very difficult to find trained Muslim personnel in Azerbaijan. When it came to using the personnel of the Republic of Azerbaijan, A. Garayev, a local Bolshevik, replied that we could not use these second-class intellectuals. Because $10-15 \%$ of them are former bailiffs, supervisors, chiefs of penitentiary police, translators, investigators, secretaries of people's courts, in short, people with a tarnished past. We cannot allow them to serve in the administration. After the establishment of the Soviet power in the district, there was a need for material resources in all areas. In general, in almost all of the documents and materials related to the city's economy, the Revolutionary Committee was asked to provide financial assistance, as well as to apply to the center on the matter. Taking into account the requests for financial assistance from the Revolutionary Committee in the district, it was decided to establish a social security department on June 10, 1920, and on June 12, Zakarayev was appointed chairman of this department (ARDA, work 2, v. 33-34).

Despite the good coverage of the social situation in Guba by the Soviet periodicals, the Social Security Department's report of 15 August 1920 acknowledged that the social security of Guba residents was in a deplorable state (ARDA, work 2 v. 31-33). The Guba district was not excluded from the general sociopolitical processes in the country, including the administrative changes in the direction of
Sovietization. As a result of the work carried out in this direction, the KGB of the Azerbaijan SSR issued a special order dated May 11, 1920 to practically abolish the internal affairs bodies of the Azerbaijan Democratic Republic. According to the order, the governor-general, the governor, the mayor, special authorities, the city and district police inspectorate, the provincial police chief, the city and district police officers, the reserve police, the governorships-general and the staffs of the people's militia under the governors, as well as other structures of the Ministry of Internal Affairs, were abolished. After the work on administrative changes was practically completed in Baku in May 1920 with the establishment of the workers 'and peasants' militia, this process continued in districts. After the arrival of the Soviets, the creation of a completely new state apparatus led to the radical reorganization of the police department. In fact, completely new law enforcement agencies have been created. Unfortunately, many valuable forms and methods of the new system, which have been tested for many years by the police in the event of an district, have been rejected. Old, experienced police officers were fired en masse (Zaplotin, 1999, p. 119).

In general, most of the militiamen organized in Guba district at that time were uneducated. Although courses were planned to eliminate militia illiteracy, work was delayed due to a lack of qualified teachers (ARDA, work 19, pp. 91-93). Party centers were established among the militia at the center of the district. Gusar, Mushkur and other areas were also actively working in this area. In addition, the militia's weapons were not in good condition and there was no strict discipline. There were cases of police misconduct due to lack of discipline. As for the supply of weapons, there were very few pistols, and almost no rifles and cartridges. Inspector Yermolov from Baku informed the center about this, but no weapons were sent to the district (ARDA, work 19, v. 91-93). The Emergency Revolutionary Committee found a way out of the administrative difficulties by organizing a sufficient number of militias at the expense of the Red Army. According to the information about the congress held on August 14-18, 1920 with the participation of the members of the district revolutionary committees, the militias have not been paid since 
the establishment of the Soviet government. they wanted. It has been 4 months since the April occupation (ARDA, work 2, v. 55-56). As of August 15, the existing 180 police officers in the district had been fired, and a total of 284 police units had been reorganized, with 97 of them held. Of these, 149 were cavalry and 132 were infantry. In addition, an estimate was drawn up for the purchase of 189 horses and sent to the People's Commissariat of Internal Affairs (ARDA, work 19, v. 75). The Guba Revolutionary Committee has taken some steps to relatively revive the work of the militia in the district. On September 10, Sharshanidze, who had served as chairman of the Gusar Revolutionary Committee, was appointed chairman of the district militia department, and Muslim, former chief of the militia, was appointed his deputy (ARDA, work 19, v. 35).

Conclusion.

One of the steps taken by the new government in the political sphere was the abolition of the former national army. On May 7, the Revolutionary Committee of Azerbaijan decided to reorganize the army and navy. According to the decision, the new Azerbaijani army and navy were, in fact, created as part of the Red Army of Soviet Russia. Azerbaijani military units were directly subordinated to the commander of the XI Red Army, and warships to the command of the Caspian fleet. Thus, from the first months of its existence, the Soviet Republic of Azerbaijan "voluntarily" renounced the right to have an armed force, which is one of the important conditions of statehood. the Soviet authorities and the 11th Army were accused of open looting in Azerbaijan under the name of "confiscation of the property of the bourgeoisie." After the work on administrative changes was practically completed in Baku in May 1920 with the establishment of the workers 'and peasants' militia, this process continued in districts. After the arrival of the Soviets, the creation of a completely new state apparatus led to the radical reorganization of the police department.

As a result of the measures taken, the situation in the militia system improved relatively in the late 1920s. The December 24, 197 issue of the Communist newspaper reported that the number of militiamen in the Guba district was 357 and that they were equipped with uniforms. A school, a literacy course and a reading room have been set up to train them and increase their technical training. Communist centers were established among the militias. The people have a good attitude towards the militia (Communist, 1920). Thus, after the establishment of Soviet power in Guba, the old system of administrative management was completely abolished and a new administrative system - the Soviet system - was established. Although this process was completed in the city of Guba and surrounding areas in the late 1920 s, the formation of new government structures in remote villages continued until mid-1921 under the influence of a number of factors. One of the main reasons for this was the growing mass discontent of the population against the policy pursued by the new regime in Guba, as in some regions of Azerbaijan, and the background of the resistance movement.

\section{REFERENCES}

ARDA. Fund 894, p. 7, work 18 [in Azerbaijani].

ARDA. Fund 894, p. 7, work 26 [in Azerbaijani].

ARDA. Fund 894, p. 7, work 32 [in Azerbaijani].

ARDA. Fund 2095, p. 1, work 2 [in Azerbaijani].

ARDA. Fund 2095, p. 1, work 4 [in Azerbaijani].

ARDA. Fund 2095, p. 1, work 6 [in Azerbaijani].

ARDA. Fund 2095, p. 1, work 8 [in Azerbaijani].

ARDA. Fund 2095, p. 1, work 19 [in Azerbaijani].

Azerbaijan Democratic Republic (1918-1920). Army (Document and materials). (1998). Baku [in Russian].

Bayramova, R. M. (2007). Conflicts and internal political disputes in the leadership of Azerbaijan (1920-1925).

Baku: Elm [in Azerbaijani].

"Communist" newspaper. (1920, December 19). [in Azerbaijani].

Dudin, I. (1970). Breakthrough of armored trains. Baku: Azerneshr [in Russian].

History of Azerbaijan. In 3 volumes. (1964). (Vol. II). Baku: EA edition [in Azerbaijani].

"Hummat" newspaper. (2008). No. 122-123 [in Azerbaijani]. 
Ibrahimli, Kh. J. (1996). Political emigration of Azerbaijan (1920-1991). Baku: Elm [in Azerbaijani]. Journal of the Revival. (2008). No. 122-123 [in Azerbaijani].

Narimanov, N. (1992). On the history of our revolution in the outskirts (letter to I. V. Stalin). Baku: Azerneshr [in Azerbaijani].

Suleymanov, M. S. (1998). Azerbaijani Army (1918-1920). Baku: Military Publishing House [in Azerbaijani].

Tokarzhevsky, E. V. (1957). From the history of foreign intervention and civil war in Azerbaijan. Baku [in Russian]. Zaplotin, G. (1999). History of Azerbaijan police. Baku [in Azerbaijani].

\section{Байрамова Рахшанда}

Докторант

Інститут історії імені А. А. Бакіханова Азербайджанської національної академії наук

\section{Bayramova Rakhshanda}

Doctoral Candidate

Institute of History named after A. A. Bakikhanov of the Azerbaijan National Academy of Sciences

ORCID: 0000-0002-1320-4286

Email: rus_rahimli@yahoo.com

Губи в Азербайджані та його трагічні наслідки (1920Цитування: Байрамов, Р. (2020). Зміна уряду в регіоні Губи в Азербайджані та його трах
1921). Науково-теоретичний альманах «Грані», 23 (9), 83-91. doi: 10.15421/172086

Citation: Bayramova, R. (2020). Change of government in the Guba region of Azerbaijan and its tragic consequences (1920-1921). Scientific and theoretical almanac «Grani», 23 (9), 83-91. doi: 10.15421/172086 